\title{
PERANCANGAN APLIKASI UJIAN ONLINE JURUSAN SISTEM KOMPUTER UNIVERSITAS DIPONEGORO
}

\author{
Tristy Meinawati, Ir. Kodrat Iman Satoto, M.T,. Dr. Oky Dwi Nurhayati, ST, MT \\ Jurusan Teknik Sistem Komputer, Fakultas Teknik, Universitas Diponegoro \\ Jl. Prof. Sudharto, Tembalang, Semarang \\ email: tristy.meina@gmail.com
}

\begin{abstract}
ABSTRAK
E-service adalah istilah untuk suatu layanan elektronik yang memanfaatkan teknologi informasi dan komunikasi untuk mempermudah penggunanya untuk melakukan suatu aktifitas tertentu. Salah satu manfaat dari e-service adalah akses yang lebih luas. Salah satu aplikasi dari e-service adalah aplikasi ujian online. Aplikasi ujian online adalah aplikasi yang bertujuan mempermudah melakukan ujian, yaitu secara online. Aplikasi ujian online difokuskan untuk ujian penerimaan mahasiswa baru pada Jurusan Sistem Komputer karena Jurusan Sistem Komputer tersebut berkaitan erat dengan teknologi informasi sehingga sewajarnya jika penerimaan mahasiswa baru dilaksanakan secara online.

Dengan menggunakan sebuah sistem basis data, ujian online ini diharapkan mempermudah sistem ujian dalam menampilkan soal-soal maupun penilaian sehingga mempermudah user untuk menggunakannya serta bagi administrator untuk mengelola soal. Dalam e-service yang dibuat kali ini adalah menggunakan PHP sebagai program aplikasi dan MySQL sebagai server basis data yang sudah terangkum dalam satu aplikasi $X A M P P$

Dengan adanya aplikasi ini diharapkan menambah minat masyarakat terhadap Jurusan Sistem Komputer Universitas Diponegoro, dan juga mempermudah pengguna untuk melakukan ujian secara online dan tidak perlu menggunakan alat tulis untuk melakukan pengerjaan.
\end{abstract}

Kata kunci : Aplikasi Ujian Online, E-service, Jurusan Sistem Komputer, PHP, MySQL

\section{PENDAhuluan}

\subsection{Latar Belakang}

Saat ini komputer, benda-benda elektronik kecil tanpa kabel dan ponsel pintar telah memudahkan kita mengakses informasi kapanpun dan dimanapun. Inti dari semua ini adalah internet, yang menempatkan kumpulan data di komputer seluruh penjuru dunia bisa diakses dengan koneksi berkecepatan tinggi (Williams, 2007). Perkembangan teknologi internet dewasa ini semakin pesat seiring dengan kebutuhan masyarakat akan layanan yang memanfaatkan internet. Aplikasi yang menggunakan manfaat dari internet adalah $e$ service. E-service adalah istilah untuk suatu layanan elektronik yang memanfaatkan teknologi informasi dan komunikasi untuk mempermudah penggunanya untuk melakukan suatu aktifitas tertentu. Saat ini sudah banyak sekali contoh aplikasi e-service yang sudah digunakan oleh masyarakat, diantaranya adalah e-banking, online shoping, hingga pembayaran listrik online.

Salah satu aplikasi dari e-service adalah aplikasi ujian online. Aplikasi ujian online adalah aplikasi yang bertujuan mempermudah melakukan ujian, yaitu secara online. Aplikasi ujian online tersebut sebagai fasilitas dan sarana bagi pengguna untuk mengasah kemampuannya dalam suatu bidang tertentu dan dalam ujian tersebut tidak terbatas oleh ruang karena dapat dilakukan dan diakses di mana saja selama terdapat akses internet. Dengan menggunakan sebuah sistem basis data, ujian online ini diharapkan mempermudah sistem ujian dalam menampilkan soal-soal maupun penilaian sehingga mempermudah user untuk menggunakannya serta bagi administrator untuk mengelola soal.

Dalam e-service yang dibuat kali ini adalah menggunakan PHP sebagai program aplikasi dan MySQL sebagai server basis data. Aplikasi difokuskan untuk ujian penerimaan mahasiswa baru pada Jurusan Sistem Komputer karena Jurusan Sistem Komputer tersebut berkaitan erat dengan teknologi informasi sehingga sewajarnya jika penerimaan mahasiswa baru dilaksanakan secara online. 


\subsection{Rumusan Masalah}

Berdasarkan latar belakang masalah tersebut, dapat dibuat suatu rumusan masalah, yaitu : bagaimana merancang aplikasi ujian online penerimaan mahasiswa baru?

\subsection{Batasan Masalah}

Dalam penulisan tugas akhir ini pembahasan masalah memiliki batasan pada permasalahan berikut :

1. Menggunakan Microsoft Windows sebagai sistem operasi client.

2. Pembuatan aplikasi dengan penekanan pada soal-soal teknologi informasi.

3. Diimplementasikan pada Jurusan Sistem Komputer.

4. Basis data yang digunakan adalah $M y S Q L$

\subsection{Tujuan Tugas Akhir}

Tujuan dari tugas akhir ini adalah merancang aplikasi ujian online pada Jurusan Sistem Komputer Universitas Diponegoro untuk penerimaan mahasiswa baru menggunakan PHP sebagai bahasa pemrograman dan MySQL sebagai basis data.

\section{TINJAUAN PUSTAKA}

\subsection{Tinjauan Pustaka}

Ujian merupakan salah satu cara untuk mengevaluasi proses belajar. Ujian dalam perguruan tinggi dapat dilaksanakan sebagai tahapan seleksi pemilihan mahasiswa yang akan masuk ke perguruan tinggi tersebut. Dengan proses ujian tersebut maka akan diperoleh data siswa yang layak dan tidak layak untuk masuk perguruan tinggi tersebut.

Teknologi komunikasi dan elektronik sudah berkembang sedemikian pesat, sehingga menyebabkan bidang pendidikan juga turut mengalami peningkatan dalam hal kualitas, kecepatan, kepraktisan dan juga kemudahan, ujian konvensionalpun bergeser ke arah komputerisasi, salah satunya dengan adanya ujian online.

\subsection{Dasar Teori}

\subsubsection{Sistem Informasi}

Menurut Ladjamudin (2007), sistem

adalah sekelompok bagian-bagian (alat dan sebagainya) yang bekerja bersama-sama untuk melakukan suatu maksud. Suatu sistem adalah jaringan kerja dari prosedur-prosedur yang saling berhubungan, berkumpul bersama-sama untuk melakukan suatu kegiatan atau menyelesaikan suatu sasaran tertentu. Gambar 2.1 menunjukkan gambaran sistem.

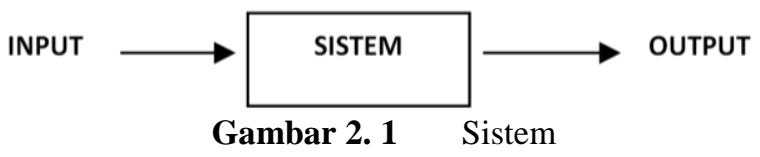

Informasi adalah data atau fakta-fakta yang telah diproses sedemikian rupa sehingga berubah bentuknya menjadi informasi.

Sistem informasi menurut Jogiyanto (2005) merupakan suatu sistem yang bertujuan menghasilkan informasi.

\subsubsection{Basis Data}

Basis data menurut Ramakrishnan (2000) adalah kumpulan data yang umumnya menjabarkan aktivitas-aktivitas dari satu atau lebih organisasi yang terkait. Basis data merupakan kumpulan dari item data yang saling berhubungan satu dengan yang lainnya yang diorganisasikan berdasarkan sebuah skema atau struktur tertentu, tersimpan di hardware komputer dan dengan software untuk melakukan manipulasi untuk kegunaan tertentu.

\subsubsection{Data Flow Diagram (DFD)}

DFD adalah alat yang menggambarkan aliran data melalui sistem pengolahan yang dilakukan oleh sistem tersebut. DFD menurut Whitekom (2003) merupakan alat yang cukup populer sekarang ini, karena dapat menggambarkan arus data di dalam sistem dengan terstruktur dan jelas.

\subsubsection{Entity Relationship Diagram (ERD)}

ERD atau diagram E-R adalah sebuah model data yang menggunakan beberapa notasi untuk menggambarkan data dalam hal entitas dan relasi yang digambarkan oleh data tersebut.

\subsubsection{MySQL}

MySQL merupakan software sistem manajemen basis data (Database Management Sistem-DBMS) yang sangat popular di kalangan 
pemrogram web. MYSQL merupakan basis data yang paling popular digunakan untuk membangun aplikasi web yang menggunakan basis data sebagai sumber dan pengelola datanya (Ariasari, 2010).

Saat ini banyak sekali perangkat lunak yang dapat dimanfaatkan untuk mengelola basis data dalam MySQL, salah satunya adalah phpMyAdmin. Dengan phpMyAdmin, seseorang dapat membuat basis data, membuat tabel, mengisi data, dan lain-lain dengan mudah, tanpa harus menghafal baris perintahnya. phpMyAdmin merupakan bagian untuk mengelola basis data $M y S Q L$ yang ada di komputer.

\subsubsection{PHP}

PHP merupakan bahasa pemrograman berbentuk script yang ditempatkan dalam server dan diproses di server yang pertama kali dibuat oleh Rasmus Lerdorf pada tahun 1995. Hasil dari pengolahan akan dikirimkan ke klien, tempat pemakai menggunakan browser. Secara khusus, PHP dirancang untuk membentuk web dinamis. Artinya, ia dapat membentuk suatu tampilan berdasarkan permintaan terkini. Misalnya, bisa menampilkan isi basis data ke halaman web (Lee, 2007).

Selain dapat digunakan untuk berbagai sistem operasi dan bersifat opensource. PHP ternyata memiliki banyak kelebihan yang tidak dimiliki oleh bahasa script sejenis, yaitu:

1.PHP dapat digunakan pada semua jenis sistem operasi seperti Windows, Linux, dan lain-lain

2.PHP memiliki kemampuan untuk mengolah keluaran gambar, file berformat pdf, dan movies Flash

3.PHP didukung oleh banyak Database Management System (DBMS) seperti MySQL, Oracle, dan lain-lain.

\section{PERANCANGAN SISTEM \\ 3.1 Data Penelitian}

Penganalisaan data secara spesifik untuk menunjang pembuatan perangkat lunak ini menghasilkan kebutuhan data yang diperlukan antara lain sebagai berikut :

1. Data login yaitu otoritas yang dibatasi untuk tingkatan pengguna aplikasi ini dimana jika seorang admin melakukan login akan berbeda dengan peserta yang menggunakan aplikasi ini.

2. Data masukan yaitu data yang harus dimasukkan ke dalam aplikasi ini untuk dapat menghasilkan keluaran, antara lain:
a. Data peserta ujian
b. Data soal ujian
c. Data jawaban ujian
d. Data nilai peserta ujian
e. Data hasil seleksi ujian

\subsection{Langkah-langkah Penelitian}

Urutan proses dalam sistem dapat digambarkan dengan simbol tertentu untuk memecahkan masalah dalam suatu program. Urutan intruksi tersebut dapat digambarkan menggunakan flowchart. Gambar 3.1 memperlihatkan flowchart aplikasi ujian online.

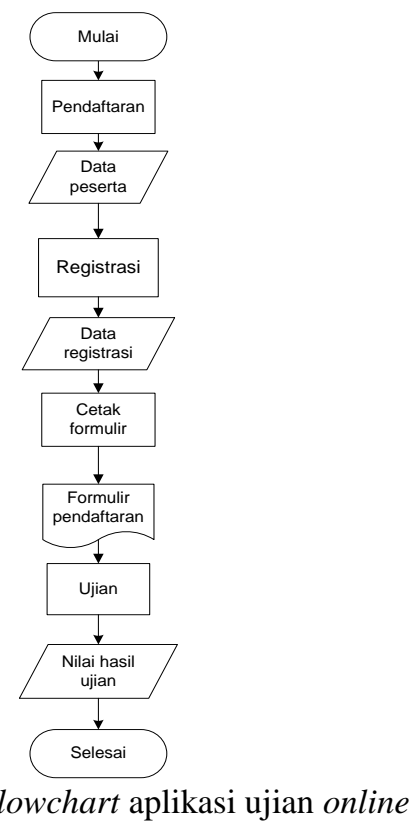

\subsection{Analisis Kebutuhan}

Analisis kebutuhan telah dilakukan baik melalui referensi-referensi berbagai media dan observasi dari lingkungan dimana sistem akan dibangun.

\subsubsection{Kebutuhan Fungsional}

Dalam pembuatan aplikasi ini ada beberapa hal yang dapat dilakukan antara lain :

a. Adanya pembagian pengguna menjadi dua kelompok dalam ujian online, yaitu :

- Peserta (dengan login) 
- Admin (dengan login)

b. Peserta dapat mendaftarkan data diri secara online.

c. Peserta dapat melakukan ujian secara online.

d. Peserta dapat mengetahui secara langsung hasil ujian yang telah selesai dikerjakan.

e. Adanya fasislitas admin untuk mengolah registrasi peserta yang telah mendaftar.

f. Adanya fasislitas admin untuk mengolah soal ujian.

g. Admin dapat mengetahu nilai ujian semua pserta atau calon mahasiswa.

h. Admin dapat menyeleksi calon mahasiswa yang akan diterima.

i. Admin dapat menampilkan daftar peserta yang diterima.

j. Peserta dapat melihat hasil seleksi.

k. Admin dapat melakukan maintenance.

\subsubsection{Kebutuhan Non-Fungsional}

Keamanan data merupakan salah satu unsur yang penting yang harus dipertimbangkan dalam proses desain suatu sistem. Karena suatu sistem tanpa keamanan data yang baik akan merugikan sistem itu sendiri, sebab data akan bebas diakses oleh pihak-pihak yang tidak bertanggung jawab. Keamanan data dapat dilakukan dengan penggunaan password dalam form login untuk admin.

\subsection{Pemodelan Perangkat Lunak}

Dalam perancangan perangkat lunak ini, digunakan metode pemodelan pemrograman terstruktur yaitu DFD (Data Flow Diagram) yang telah menjadi standar dalam industri untuk mengetahui aliran data dalam sebuah program.

\subsubsection{Konteks Diagram}

Konteks diagram ini merupakan gambaran dasar dari sistem aplikasi ujian online yang nantinya akan didekomposisi menjadi sistem yang lebih detail. Gambar 3.2 memperlihatkan konteks diagram aplikasi Ujian Online Jurusan Sistem Komputer.

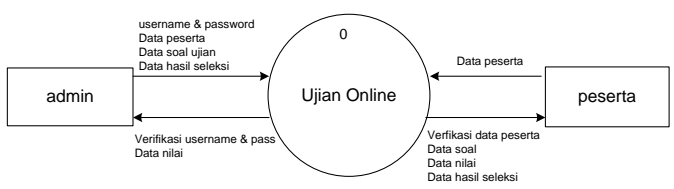

Gambar 3.2 Konteks Diagram
Gambar 3.2 menunjukkan bahwa terdapat dua user yang terlibat, yaitu admin dan peserta.

\subsubsection{DFD Level 1}

DFD dari aplikasi ujian online diperlihatkan pada gambar 3.3. Pada DFD level 1 ini terdapat 4 (empat) proses, yaitu :

1. Otorisasi

Merupakan proses pemisahan user dalam mengakses ujian online. Terdapat dua user yang terlibat dalam ujian online ini, yaitu admin dan peserta. Dimana setiap user memiliki otoritas tertentu dalam mengakses sistem ini.

2. Ujian

Merupakan proses yang dilaksanakan peserta dimana peserta dapat melakukan ujian secara online dengan diberi waktu yang telah ditentukan oleh program.

3. Lihat Nilai

Merupakan kelanjutan dari proses ujian. Proses ini berfungsi memperlihatkan nilai hasil ujian yang dilaksanakan peserta. Peserta hanya dapat melihat nilainya sendiri setelah melakukan ujian, sedangkan admin dapat melihat nilai semua peserta yang telah melakukan ujian online.

4. Seleksi

Merupakan proses yang hanya dapat dilakukan oleh admin dengan pertimbangan tertentu. Setelah admin menentukan hasil seleksi, peserta dapat melihat daftar hasil seleksi tersebut.

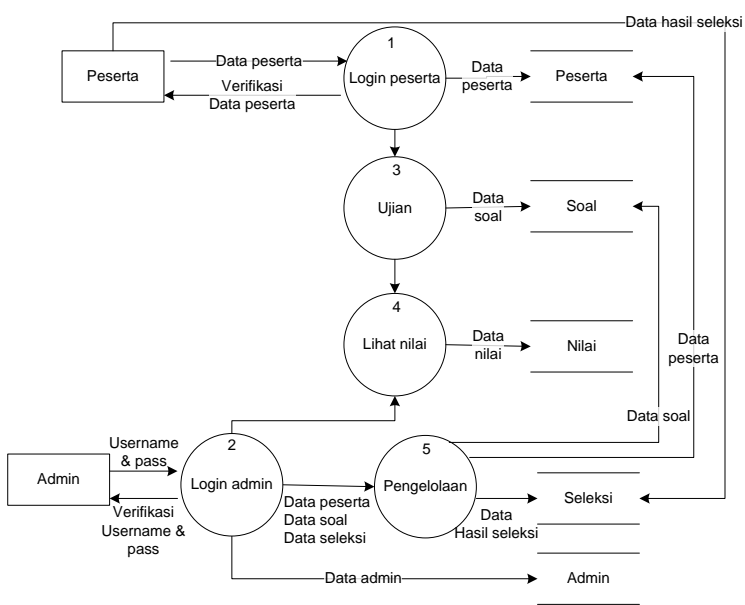

Gambar 3.3 DFD Level 1 


\subsection{Perancangan Basis Data}

Perancangan basis data untuk membangun aplikasi ujian online dibutuhkan suatu pendekatan yang digunakan untuk menggambarkan hubungan antar data. Hubungan tersebut dapat dinyatakan dalam bentuk ERD (Entity Relationship Diagram).

\subsubsection{Entity Relationship Diagram (ERD)}

Dalam perancangan basis data, metode yang digunakan adalah ERD (Entity Relationship Diagram), metode ini menyajikan data dengan menggunakan Entity dan Relationship. Gambar 3.9 adalah gambaran ERD dari aplikasi ujian online.

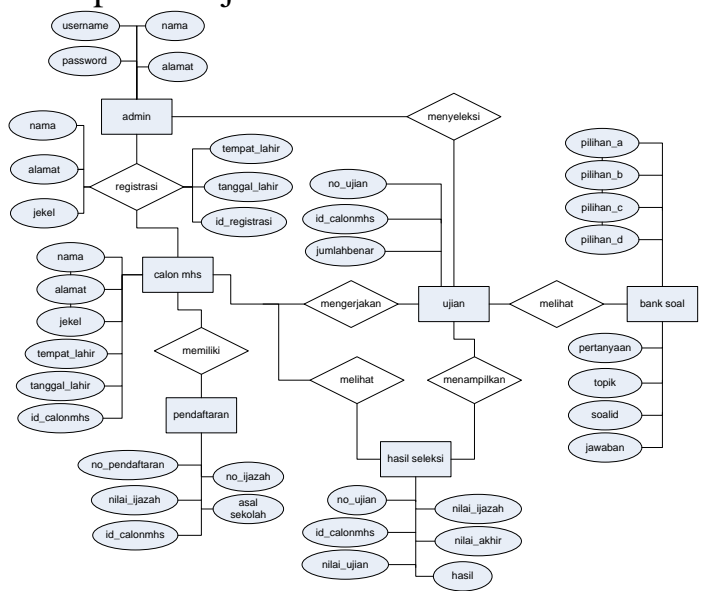

Gambar 3.9 Entity Relationship Diagram

\section{PENGUJIAN SISTEM}

\section{Backbox}

Pengujian black box dilakukan dengan mengeksekusi unit kemudian diamati apakah sesuai dengan proses bisnis yang diinginkan. Tabel 4.1 adalah pengujian blackbox aplikasi Ujian Online Jurusan Sistem Komputer Universitas Diponegoro.

Tabel 4.1 Pengujian blackbox

\begin{tabular}{|l|l|l|l|l|}
\hline $\begin{array}{l}\text { Nama } \\
\text { Pengujian }\end{array}$ & Masukan & $\begin{array}{l}\text { Hasil yang } \\
\text { Diharapkan }\end{array}$ & Keluaran & $\begin{array}{l}\text { Hasil } \\
\text { Pengujian }\end{array}$ \\
\hline $\begin{array}{l}\text { Pengujian } \\
\text { menu } \\
\text { pendaftaran } \\
\text { peserta }\end{array}$ & $\begin{array}{l}\text { Klik menu } \\
\text { pendaftaran } \\
\text { menu } \\
\text { mahasiswa } \\
\text { baru }\end{array}$ & $\begin{array}{l}\text { Muncul } \\
\text { tampilan } \\
\text { form } \\
\text { pendaftaran }\end{array}$ & $\begin{array}{l}\text { Form } \\
\text { pendaftara } \\
\mathrm{n}\end{array}$ & Berhasil \\
\hline $\begin{array}{l}\text { Pengujian } \\
\text { pendaftaran } \\
\text { peserta }\end{array}$ & $\begin{array}{l}\text { Memasukk } \\
\text { an data diri } \\
\text { peserta }\end{array}$ & $\begin{array}{l}\text { Data } \\
\text { tersimpan }\end{array}$ & $\begin{array}{l}\text { Laporan } \\
\text { data } \\
\text { tersimpan }\end{array}$ & Berhasil \\
\hline $\begin{array}{l}\text { Pengujian } \\
\text { cetak } \\
\text { formulir }\end{array}$ & $\begin{array}{l}\text { Klik menu } \\
\text { cetak } \\
\text { formulir }\end{array}$ & $\begin{array}{l}\text { Muncul } \\
\text { tampilan } \\
\text { formulir }\end{array}$ & $\begin{array}{l}\text { Tampilan } \\
\text { formulir }\end{array}$ & Berhasil \\
\hline $\begin{array}{l}\text { Pengujian } \\
\text { ujian } \text { online }\end{array}$ & $\begin{array}{l}\text { Klik menu } \\
\text { ujian online }\end{array}$ & $\begin{array}{l}\text { Muncul } \\
\text { tampilan } \\
\text { ujian }\end{array}$ & $\begin{array}{l}\text { Tampilan } \\
\text { ujian }\end{array}$ & Berhasil \\
\hline
\end{tabular}

\begin{tabular}{|c|c|c|c|c|}
\hline $\begin{array}{l}\text { Pengujian } \\
\text { login }\end{array}$ & $\begin{array}{l}\text { Memasukk } \\
\text { an } \\
\text { username } \\
\text { dan } \\
\text { password }\end{array}$ & $\begin{array}{l}\text { Muncul } \\
\text { tampilan } \\
\text { halaman } \\
\text { utama admin }\end{array}$ & $\begin{array}{l}\text { Tampilan } \\
\text { halaman } \\
\text { utama } \\
\text { admin }\end{array}$ & Berhasil \\
\hline $\begin{array}{l}\text { Pengujian } \\
\text { menu soal }\end{array}$ & $\begin{array}{l}\text { Klik menu } \\
\text { soal }\end{array}$ & $\begin{array}{l}\text { Muncul } \\
\text { tampilan } \\
\text { menu soal }\end{array}$ & $\begin{array}{l}\text { Tampilan } \\
\text { menu soal }\end{array}$ & Berhasil \\
\hline $\begin{array}{l}\text { Nama } \\
\text { Pengujian }\end{array}$ & Masukan & $\begin{array}{l}\text { Hasil yang } \\
\text { Diharapkan }\end{array}$ & Keluaran & $\begin{array}{l}\text { Hasil } \\
\text { Pengujian }\end{array}$ \\
\hline $\begin{array}{l}\text { Pengujian } \\
\text { menu tambah } \\
\text { soal }\end{array}$ & $\begin{array}{l}\text { Klik menu } \\
\text { tambah data }\end{array}$ & $\begin{array}{l}\text { Muncul } \\
\text { tampilan } \\
\text { tambah soal }\end{array}$ & $\begin{array}{l}\text { Tampilan } \\
\text { tambah } \\
\text { soal }\end{array}$ & Berhasil \\
\hline $\begin{array}{l}\text { Pengujian } \\
\text { menu } \\
\text { registrasi }\end{array}$ & $\begin{array}{l}\text { Klik menu } \\
\text { registrasi }\end{array}$ & $\begin{array}{l}\text { Muncul } \\
\text { tampilan } \\
\text { registrasi }\end{array}$ & $\begin{array}{l}\text { Tampilan } \\
\text { registrasi }\end{array}$ & Berhasil \\
\hline $\begin{array}{l}\text { Pengujian } \\
\text { menu aksi } \\
\text { registrasi }\end{array}$ & $\begin{array}{l}\text { Klik } \\
\text { centang } \\
\text { pada kolom } \\
\text { aksi } \\
\end{array}$ & $\begin{array}{l}\text { Data berhasil } \\
\text { disimpan }\end{array}$ & $\begin{array}{l}\text { Laporan } \\
\text { data } \\
\text { tersimpan }\end{array}$ & Berhasil \\
\hline $\begin{array}{l}\text { Pengujian } \\
\text { menu calon } \\
\text { mahasiswa }\end{array}$ & $\begin{array}{l}\text { Klik menu } \\
\text { calon } \\
\text { mahasiswa }\end{array}$ & $\begin{array}{l}\text { Muncul } \\
\text { tampilan } \\
\text { menu calon } \\
\text { mahasiswa }\end{array}$ & $\begin{array}{l}\text { Tampilan } \\
\text { menu } \\
\text { calon } \\
\text { mahasisw } \\
\text { a }\end{array}$ & Berhasil \\
\hline $\begin{array}{l}\text { Pengujian } \\
\text { menu } \\
\text { pendaftar }\end{array}$ & $\begin{array}{l}\text { Klik menu } \\
\text { pendaftar }\end{array}$ & $\begin{array}{l}\text { Muncul } \\
\text { tampilan } \\
\text { menu } \\
\text { pendaftar }\end{array}$ & $\begin{array}{l}\text { Tampilan } \\
\text { menu } \\
\text { pendaftar }\end{array}$ & Berhasil \\
\hline $\begin{array}{l}\text { Pengujian } \\
\text { menu hasil } \\
\text { ujian }\end{array}$ & $\begin{array}{l}\text { Klik menu } \\
\text { hasil ujian }\end{array}$ & $\begin{array}{l}\text { Muncul } \\
\text { tampilan } \\
\text { menu hasil } \\
\text { ujian }\end{array}$ & $\begin{array}{l}\text { Tampilan } \\
\text { menu } \\
\text { hasil ujian }\end{array}$ & Berhasil \\
\hline $\begin{array}{l}\text { Pengujian } \\
\text { proses hasil } \\
\text { ujian }\end{array}$ & $\begin{array}{l}\text { Klik } \\
\text { centang } \\
\text { pada kolom } \\
\text { proses }\end{array}$ & $\begin{array}{l}\text { Muncul } \\
\text { tampilan } \\
\text { proses }\end{array}$ & $\begin{array}{l}\text { Tampilan } \\
\text { proses }\end{array}$ & Berhasil \\
\hline $\begin{array}{l}\begin{array}{l}\text { Pengujian } \\
\text { menu } \\
\text { seleksi }\end{array} \\
\end{array}$ & $\begin{array}{l}\text { Klik menu } \\
\text { hasil seleksi }\end{array}$ & $\begin{array}{l}\text { Muncul } \\
\text { tampilan } \\
\text { hasil seleksi }\end{array}$ & $\begin{array}{l}\text { Tampilan } \\
\text { hasil } \\
\text { seleksi } \\
\end{array}$ & Berhasil \\
\hline $\begin{array}{l}\text { Pengujian } \\
\text { logout }\end{array}$ & & $\begin{array}{ll}\text { Kembali } & \text { ke } \\
\text { halaman } & \\
\text { utama } & \\
\end{array}$ & $\begin{array}{l}\text { Tampilan } \\
\text { halaman } \\
\text { utama }\end{array}$ & Berhasil \\
\hline
\end{tabular}

\section{Pengujian Pendaftaran Peserta}

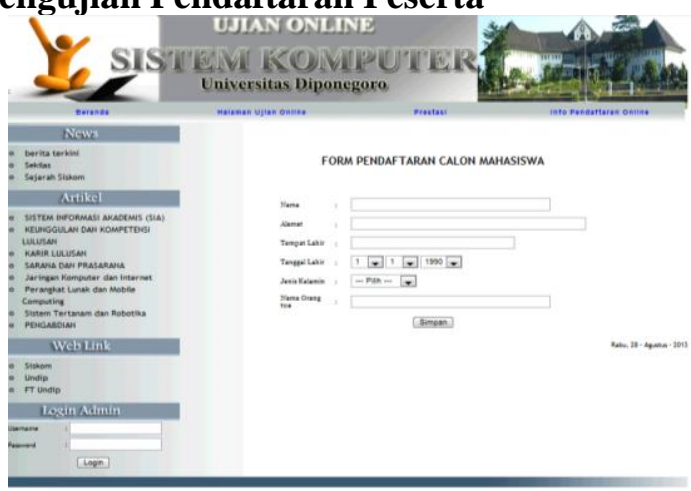

Gambar 4.1 Tampilan menu pendaftaran peserta Pada gambar terdapat form pendaftaran calon mahasiwa yang harus diisi dengan data diri peserta. Setelah melakukan pengisian, kemudian klik tombol simpan, maka data akan disimpan pada basis data. Setelah melakukan pendaftaran, hal yang dilakukan adalah mendapat persetujuan dari admin agar dapat melakukan proses selanjutnya. 


\section{Pengujian Cetak Formulir Pendaftaran}

Sebelum melakukan cetak formulir, akan muncul form kelengkapan data pendaftaran. Gambar 4.2 menunjukkan gambar form kelengkapan data pendaftaran.

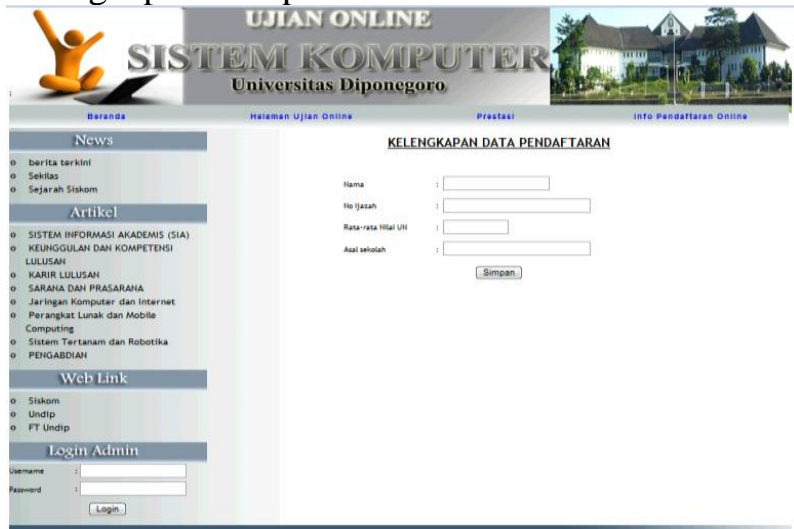

Gambar 4.2 Form kelengkapan data pendaftaran Setelah melengkapi data pendaftaran proses selanjutnya adalah melakukan cetak formulir. Gambar 4.3 menunjukkan formulir pendaftaran calon mahasiswa.

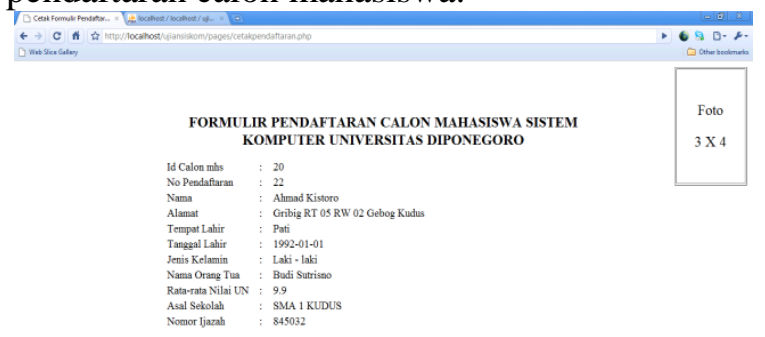

Gambar 4.3 Formulir pendaftaran calon mahasiswa

Dengan mengklik tombol cetak maka formulir tersebut dapat dicetak. Formulir tersebut dapat digunakan sebagai bukti bahwa peserta telah melakukan pendaftaran.

\section{Pengujian Ujian Online}

Sebelum melakukan ujian, peserta diharuskan melakukan login untuk dapat melakukan ujian. Gambar 4.4 adalah gambar tampilan login peserta sebelum melakukan ujian online.

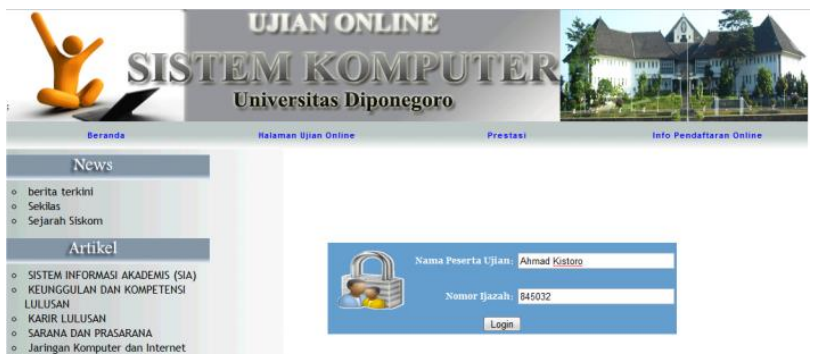

Gambar 4.4 Login peserta ujian online

Pada gambar tersebut terlihat pada login peserta mengisikan kombinasi nama peserta ujian dan nomor ijazah peserta ujian. Gambar 4.5 merupakan tampilan pelaksanaan ujian online.

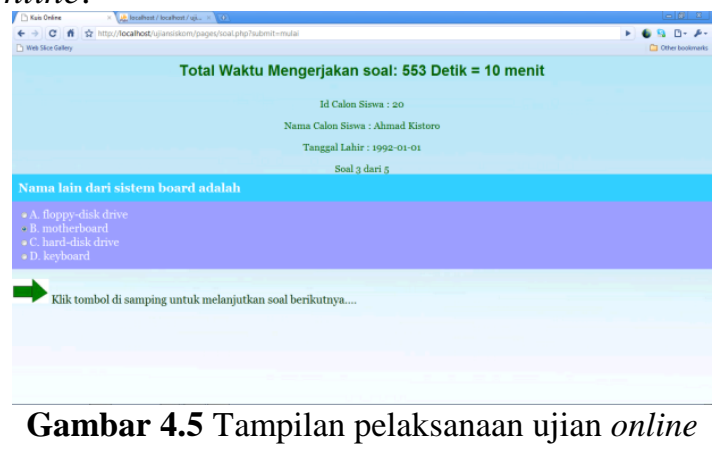

Gambar 4.6 merupakan tampilan hasil penilaian setelah melakukan ujian online.

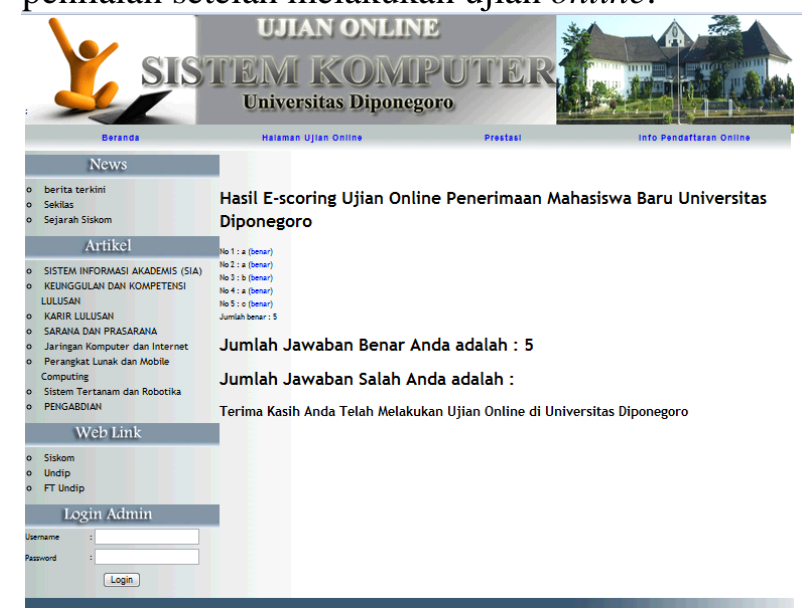

Gambar 4.6 Hasil penilaian ujian online

Pada tampilan tersebut diperlihatkan hasil pengerjaan ujian. Hasil tersebut menampilkan jumlah jawaban benar dan jawaban yang salah. 


\section{Pengujian Lihat Pengumuman}

Peserta dapat melihat pengumuman setelah hasil ujian para peserta diseleksi oleh admin. Gambar 4.7 menunjukkan tampilan lihat pengumuman.

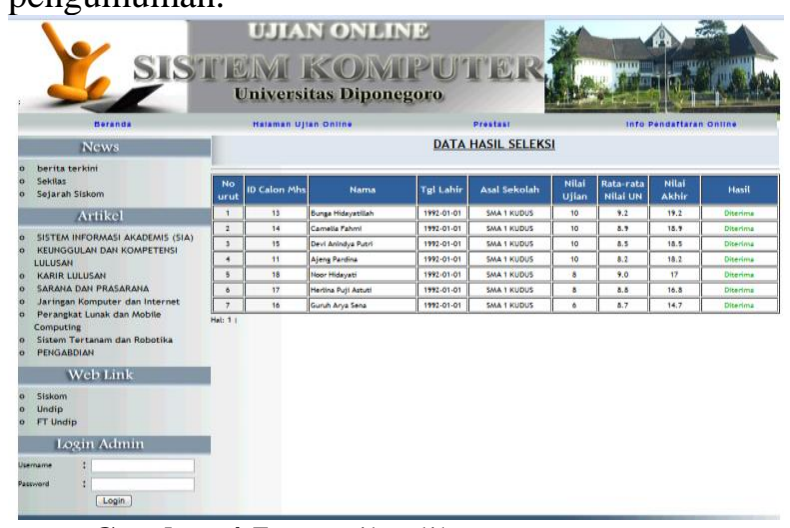

Gambar 4.7 Tampilan lihat pengumuman

\section{Pengujian Login Admin}

Gambar 4.8 merupakan tampilan login admin.

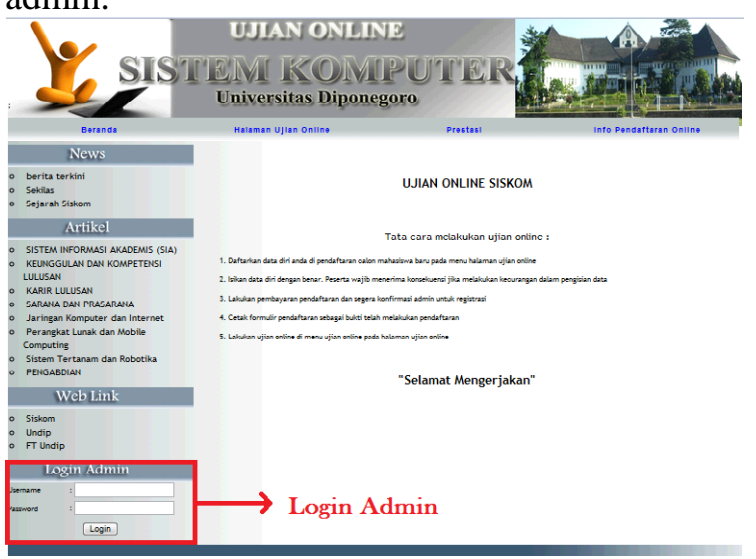

Gambar 4.8 Login admin

Login admin terletak di bagian pojok kiri bawah halaman utama. Admin harus memasukkan kombinasi username dan password dengan benar.

\section{Pengujian Menu Soal}

Gambar 4.9 adalah tampilan menu soal yang dapat diakses oleh admin.

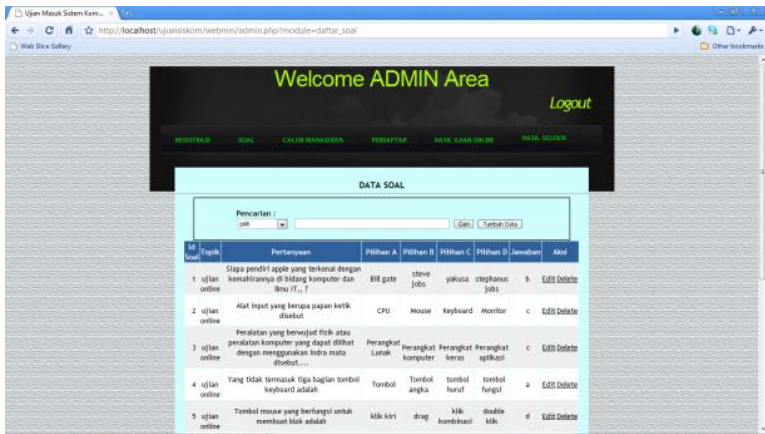

Gambar 4.9 Menu soal

Pada gambar tersebut terlihat beberapa kolom, yaitu id Soal, Topik, Pertanyaan, Pilihan A, Pilihan B, Pilihan C, Pilihan D, Jawaban, dan Aksi. Admin dapat melakukan pengolahan data soal, yaitu edit, delete, dan tambah soal.

\section{Pengujian Menu Registrasi}

Gambar 4.10 merupakan tampilan menu registrasi.

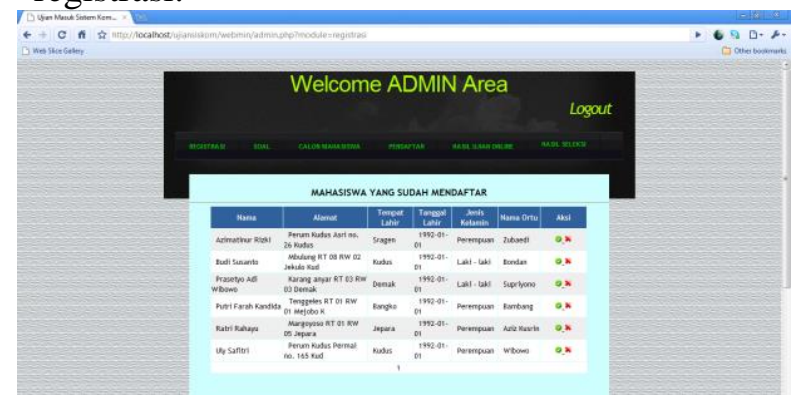

Gambar 4.10 Menu registrasi

Pada menu tersebut terdapat data-data para peserta yang telah mendaftarkan dirinya dan menunggu mendapat persetujuan admin agar bisa melakukan proses selanjutnya dan bisa melakukan ujian online.

\section{Pengujian Menu Data Calon Mahasiswa}

Gambar 4.11 merupakan tampilan menu data calon mahasiswa.

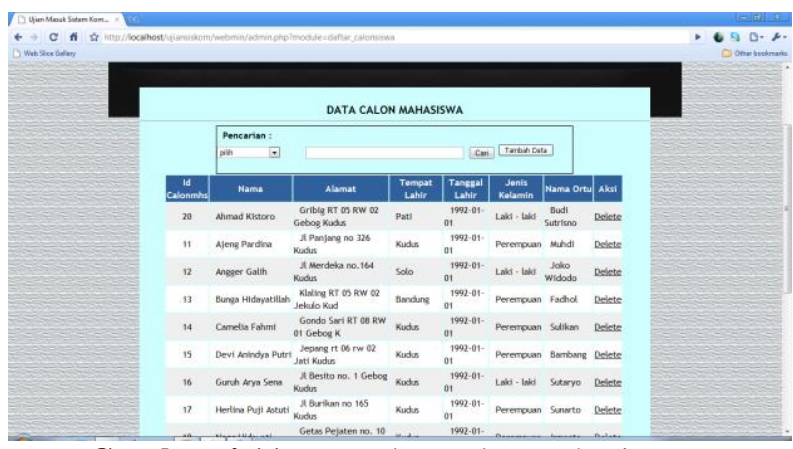

Gambar 4.11 Menu data calon mahasiswa Setelah mendapat persetujuan dari admin, 
maka data peserta akan berpindah dari menu register ke menu data calon mahasiswa.

\section{Pengujian Menu Pendaftaran}

Gambar 4.12 merupakan tampilan menu pendaftaran pada halaman admin.

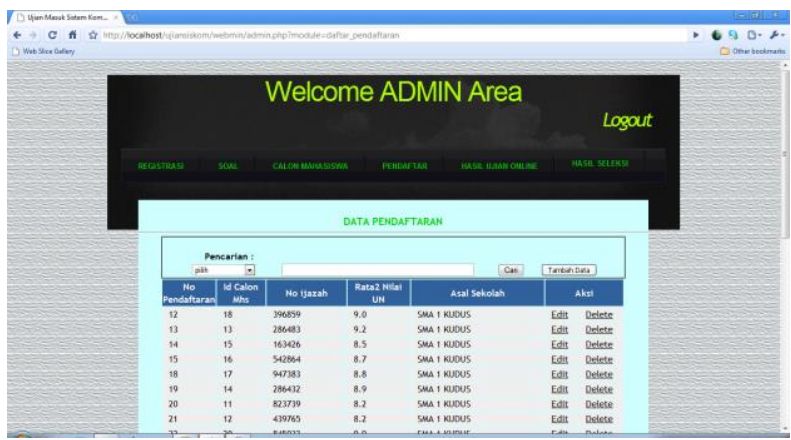

Gambar 4.12 Menu pendaftaran

Menu tersebut berisi kelengkapan data pendaftaran yaitu meliputi data asal sekolah, nilai peserta, dan nomor ijazah peserta yang telah mendaftar ujian online.

\section{Pengujian Menu Hasil Ujian Online}

Gambar 4.13 menunjukkan tampilan hasil ujian online yang dapat diakses oleh admin.

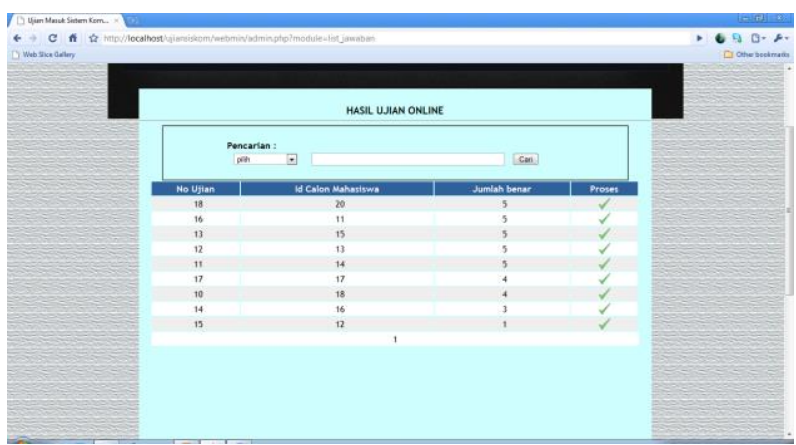

Gambar 4.13 Tampilan hasil ujian online

Menu tersebut menunjukkan data hasil para peserta yang telah melakukan ujian online beserta jumlah nilai yang telah diperoleh. Pada menu tersebut admin dapat melakukan proses untuk melakukan seleksi terhadap para peserta. Gambar 4.14 adalah tampilan proses seleksi yang dapat dilakukan oleh admin.

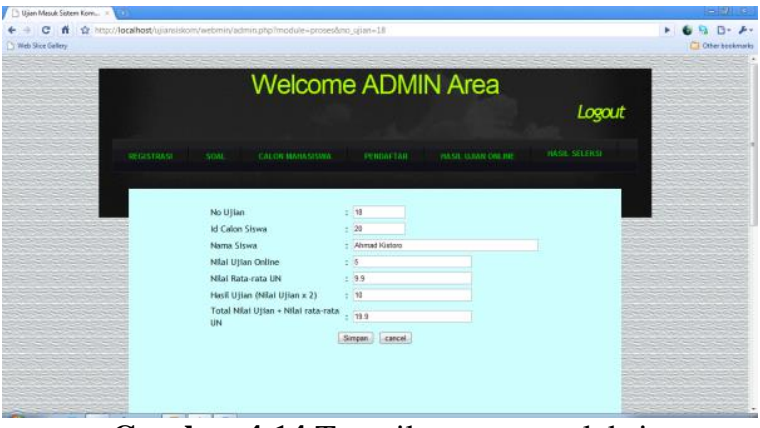

Gambar 4.14 Tampilan proses seleksi

Pada gambar tersebut ditunjukkan tampilan proses seleksi yang dilakukan oleh admin. . Gambar 4.15 adalah tampilan menu hasil seleksi.

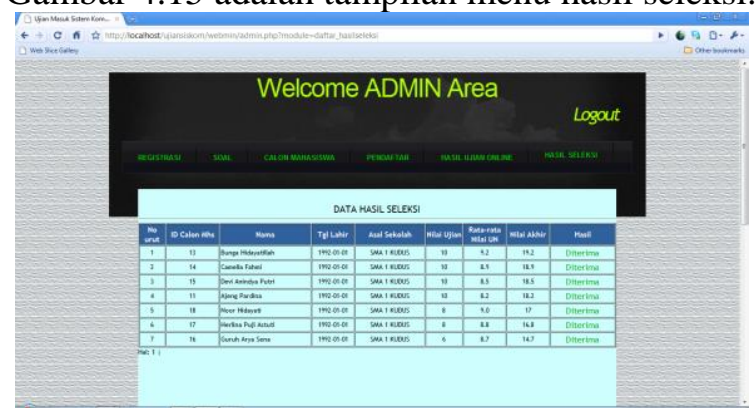

Gambar 4.15 Tampilan hasil seleksi

Pada gambar 4.15 ditunjukkan menu hasil seleksi yang terdapat pada halaman admin.

\section{PENUTUP}

\subsection{Kesimpulan}

1. Aplikasi ujian online adalah salah satu contoh e-service yang bertujuan untuk mempermudah melakukan ujian, yaitu secara online.

2. Aplikasi ujian online penerimaan mahasiswa baru dirancang dengan menggunakan bahasa pemrograman PHP dan basis data MySQL yang berjalan pada web server Apache.

3. Aplikasi ujian online telah berhasil dirancang dan berjalan dengan baik.

4. Aplikasi ujian online penerimaan mahasiswa baru memiliki dua user, yaitu admin dan peserta.

5. Aplikasi ujian online penerimaan mahasiswa baru dapat diakses dengan web browser dan berdasarkan pengujian terhadap aplikasi yang dibuat, seluruh fungsi menu yang ada dalam aplikasi tersebut telah berhasil sesuai dengan fungsinya. 


\subsection{Saran}

1. Aplikasi ujian online penerimaan mahasiswa baru dapat dikembangkan lebih lanjut agar sistem yang digunakan dapat menjadi lebih baik dan menambah fitur agar lebih lengkap.

2. Perlu dilakukan penelitian lebih lanjut untuk menyempurnakan aplikasi ini untuk menmbah proses pembayaran biaya pendaftaran.

3. Perlu dilakukan penelitian lebih lanjut agar aplikasi ujian online dapat ditanamkan pada perangkat mobile.

\section{DAFTAR PUSTAKA}

Adi, A.P dan Sanjay, R, 2012, Web Makin Dahsyat dengan JQuery. Semarang : Kompas Gramedia.

Al Fatta, Hanif, 2007, Analisis dan Perancangan Sistem Informasi untuk Keunggulan Bersaing Perusahaan dan Organisasi Modern, Yogyakarta : CV. Andi Offset.

Ariasari, Fany, 2010, Panduan Praktis Bikin Blog dengan Wordpress. Jakarta : Media Kita.

Craig, R. D. dan S. P. Jaskiel, 2002, Systematic Software Testing. Norwood MA: Artech House Publis.

Darmawan, Dilar. Aplikasi PHP pada Website Online Examination.

http://id.wikipedia.org/wiki/Server_web, diakses januari 2013

Jogiyanto, H.M, 2005, Sistem Teknologi Informasi Edisi 2. Yogyakarta : Andi.

Kadir, Abdul, 2008, Dasar Pemrograman WEB Dinamis menggunakan PHP, Penerbit Andi

Kadir, Abdul, 2008, Dasar Perancangan \& Implementasi Database Relasional, Yogyakarta : CV. Andi Offset.

Kadir, Abdul, 2009, Mastering AJAX dan PHP. Yogyakarta : CV. Andi Offset.

Kusnendar, Jajang dan Wahyudi, Asep, 2006, Pemanfaatan Remote Desktop untuk Optimalisasi Sistem Ujian Online.

Lee Babin Programmer, 2007, Beginning Ajax With PHP from Novice to Profesional.

Ladjamudin, Al Bahra Bin, 2007, Analisis dan
Desain Sistem Informasi, Yogyakarta : Penerbit Graha Ilmu.

Mata, A.Ramon, dkk., 2007, Dasar-Dasar Database Relasional. Schaum's Otline, Jakarta : Erlangga..

Ramadhan, Arief, 2006, SGS : Pemr.Web Database PHP\&MySQL. Jakarta : Elex Media Komputindo.

Ramakrishnan, Raghu, Gerkhe, Johannes, 2000, Database Management Systems, USA: The McGraw-Hill Companies, Inc.

Syafi'i. 2009. Rancang Bangun Aplikasi Online untuk Ujian Masuk Jalur Reguler Di Universitas Islam Negeri(UIN) Maulana Malik Ibrahim Malang.

Wahyono, Teguh, 2009, Practice Guide PHP On Windows, Jakarta : PT. Elex Media Komputindo.

Whitekom, Mark dan Mark, Bill, 2003, Seluk Beluk Database Relasional. Jakarta: Erlangga.

Williams, K. Brian dan Sawyer, C. Stacey, 2007, Using Information Technology. Penerbit Andi 


\section{BIODATA PENULIS}

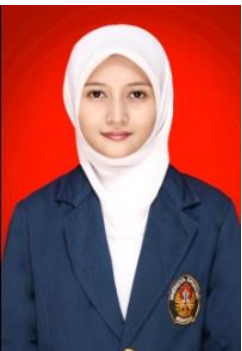

Tristy Meinawati, lahir di kota Kudus 18 Mei 1990.

Menjalani pendidikan di TK

Pertiwi Gribig II, SD 2

Gribig, SMP 1 Kudus, SMA 1

Kudus, dan sekarang tengah menyelesaikan pendidikan Strata Satu di Jurusan Teknik Sistem Komputer, Universitas Diponegoro, Semarang, Indonesia Angkatan Tahun 2008.

Menyetujui,

Dosen Pembimbing I

\section{Ir. Kodrat Iman Satoto, M.T.}

NIP. 196310281993031002

Dosen Pembimbing II

Dr. Oky Dwi Nurhayati, S.T., M.T.

NIP. 197910022009122001 